\title{
DENDROECOLOGICAL DATING OF GEOMORPHIC DISTURBANCE IN TREES
}

\author{
MARKUS STOFFEL ${ }^{1,2}$ and CHRISTOPHE CORONA ${ }^{1,3}$ \\ ${ }^{1}$ University of Berne, Institute of Geological Sciences, dendrolab.ch, Baltzerstrasse 1+3, CH-3012 Berne, Switzerland \\ ${ }^{2}$ University of Geneva, Institute for Environmental Sciences, Chair for Climate Change and Climate Impacts, \\ 7 chemin de Drize, CH-1227 Carouge, Switzerland \\ ${ }^{3}$ Centre National de Recherche Scientifique (CNRS) UMR6042 Geolab, 4 rue Ledru, F-63057 Clermont-Ferrand Cedex, \\ France
}

\begin{abstract}
The initial employment of tree rings in geomorphic studies was simply as a dating tool and only rarely were other environmental information and records of damage contained within the tree exploited. However, these annually resolved tree-ring records also preserve valuable archives of past geomorphic processes on timescales of decades to centuries. As many of these processes are significant natural hazards, understanding their distribution, timing and controls provides crucial information that can assist in the prediction, mitigation and defense against these hazards and their effects on society. This contribution aims at presenting a proposal on the types of growth disturbances to be included in future work focusing on geomorphic disturbance, the intensity of reactions, and on the minimum requirements needed for growth disturbances to be considered in event histories. We present possibilities and limitations of dendrogeomorphic applications in geomorphic research and propose a range of techniques and approaches that may become standard practice in the analysis and understanding of earth-surface processes and related natural hazards in the future.
\end{abstract}

Keywords: dendrogeomorphology, wood anatomy, earth-surface process, hydrogeomorphology, geomorphology, injury, resin duct, reaction wood, vessel, tracheid.

\section{INTRODUCTION}

A major key to the assessment of ongoing hazards and risks is the documentation of geomorphic processes and related natural disasters (Stoffel and Huggel 2012). In many cases, because of the absence of documentary records, this information must be developed from natural archives or "silent witnesses" (Aulitzky 1992) that remain visible in the landscape after an event. In addition to the geomorphic or sedimentologic evidence, key information is required on the dating and history of past events. The significant contribution of tree rings to these endeavors lies in their capacity to preserve evidence of past geomorphic activity - in the context of this paper, the generic term "geomorphic activity" summarizes falls, topples, slides, spreads, and flows (Varnes 1978), as well as the interactions and linkages of hydrologic processes with landforms and the interaction of geomorphic processes with water (i.e. hydrogeomorphology; Sidle and Onda 2004) - and to provide critical information on their dating with annual or sub-annual resolution. Therefore, in many climates, the tree-ring record may represent one of the most valuable and precise natural archives for the reconstruction and understanding of past and ongoing processes during the past several hundred years (Stoffel and Bollschweiler 2008; Stoffel et al. 2010).

The initial employment of tree rings in geomorphic studies was simply as a dating tool (Douglass 1941; Stokes and Smiley 1968) - it rarely exploited other environmental information that could be derived from studies of ring-width variations and records of growth anomalies contained within the tree. However, these unique, annually resolved, tree-ring records preserve potentially valuable archives of past geomorphic processes. As many geomorphic processes are also 
Table 1. Growth disturbances used to infer geomorphic process activity. Analysis is based on 206 contributions published in journals and indexed conference proceedings. Over the past five years, studies have increasingly focused on tangential rows of traumatic resin ducts (TRDs), whereas papers focusing on adventitious roots and germination have become more scarce.

\begin{tabular}{|c|c|c|c|c|}
\hline Growth disturbance & Citations (all) & $\%$ & Citations (2008-2012) & $\%$ \\
\hline Injuries/callus tissue & 142 & 0.25 & 63 & 0.26 \\
\hline TRDs & 51 & 0.09 & 34 & 0.14 \\
\hline Tracheid anomalies & 4 & 0.01 & 3 & 0.01 \\
\hline Vessel anomalies & 20 & 0.04 & 9 & 0.04 \\
\hline Reaction wood & 122 & 0.21 & 51 & 0.21 \\
\hline Growth reduction & 114 & 0.20 & 46 & 0.19 \\
\hline Growth release & 55 & 0.10 & 23 & 0.10 \\
\hline Kill dates & 18 & 0.03 & 5 & 0.02 \\
\hline Germination & 30 & 0.05 & 5 & 0.02 \\
\hline Adventitious roots & 15 & 0.03 & 3 & 0.01 \\
\hline Total & 571 & 1.00 & 242 & 1.00 \\
\hline Papers & & $\mathrm{n}=206$ & & $\mathrm{n}=75$ \\
\hline
\end{tabular}

significant natural hazards, understanding their distribution, timing and controls provides valuable information that can assist in the development of mitigation and defense against these hazards and their effects on society (Osterkamp et al. 2012; Stoffel and Wilford 2012).

Apart from the site-specific information common to many trees at any site, individual trees also record the effects of mechanical disturbance caused by external processes. In his seminal work, Alestalo (1971) illustrated that the occurrence of earthsurface processes will typically injure trees, tear off their crown or branches, tilt their stems, partially bury them or expose their roots. Evidence of these events can be recorded in growth-ring records of affected trees (Shroder 1978). Based on the principles presented in these seminal papers (Butler and Stoffel 2013), a set of characteristic growth disturbances has been typically used in dendrogeomorphic studies (Stoffel et al. 2013a) with a clear focus on injuries, reaction wood and growth suppression (Table 1). Other indicators, such as tangential rows of traumatic resin ducts (TRDs), have been used much less often and only became a widely accepted signal for past geomorphic disturbance in trees over the past few years $(9 \%$ overall, but $14 \%$ since 2008). Despite the ever increasing popularity of dendrogeomorphology (Table 1), a common understanding of parameters to be used and a weighting of indicators is largely missing, and the reconstruction of time series of events is still based on largely varying criteria.
This contribution thus aims at presenting a proposal on (i) which growth disturbances (GDs) to focus on in future work addressing geomorphic disturbance, (ii) how to determine their intensity, (iii) what minimum requirements for GDs should be considered in event histories, which will then eventually lead to (iv) the establishment of a range of techniques and approaches that may become standard practice in the analysis of specific geomorphic, geologic and hydrologic processes in the future.

\section{GROWTH REACTIONS INDUCED BY GEOMORPHIC PROCESSES}

\section{Injuries and Callus Tissue}

Partial bark removal and wood-penetrating injuries are a common feature in trees affected by geomorphic processes (Lundström et al. 2009; Trappmann and Stoffel 2013). Wounds can occur on the tree's stem (Figure 1A), its branches or on roots. If impacts locally destroy the cambium, incremental cell formation will become disrupted and new cell formation will cease in the injured segment of the tree. To minimize rot and the negative effects of insect attacks after damage, the injured tree will compartmentalize the wound (e.g. Shigo 1984; Stoffel and Klinkmüller, 2013) and start the production of chaotic callus tissue at the edges of the injury (Figure 1B). Through the production of callus tissue, cambium cells will continuously overgrow the injury from its edges 

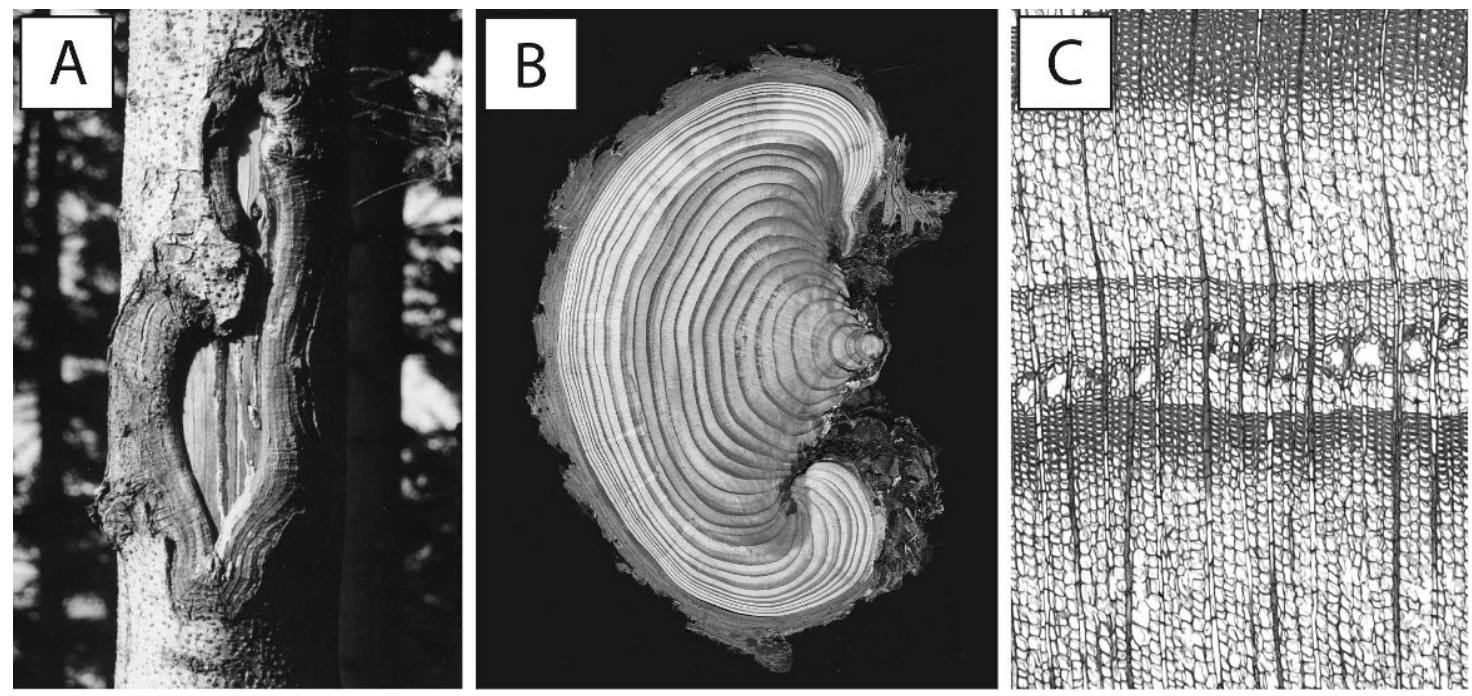

Figure 1. (A) Open injury in Abies alba and (B) on a cross-section of a wounded Larix decidua tree. (C) Micro-section of a tangential row of traumatic resin ducts in Larix decidua. Note the delayed response with increasing distance from the wound (left to right).

(Sachs 1991) and ideally can lead to the complete closure of the wound. The extent of wound healing will, however, greatly depend on the annual increment rate, tree age and on scar size (Bollschweiler et al. 2008a; Schneuwly et al. 2009a).

The presence of injuries and chaotic callus tissue is commonly regarded as a valuable and reliable indicator of past geomorphic process activity. Provided that trees are selected with sufficient care in the field and that disturbances other than geomorphic (e.g. anthropogenic, ungulate browsing or fraying, lightning strike, or hail) can be excluded, they represent the most unambiguous witness of past disturbance. As a rule of thumb, we recommend excluding elongated $(>2 \mathrm{~m})$ and very small $\left(<20 \mathrm{~cm}^{2}\right)$ injuries from analyses, and not to take injuries in very small trees $(\mathrm{DBH}$ $<5 \mathrm{~cm}$ ) into account. In addition, whereas scars will remain largely visible on the stem surface of tree species with smooth barks (e.g. Abies, Alnus, Betula, Fagus; Trappmann and Stoffel 2013), they may become fully blurred in species with thicker bark structures such as Larix, Picea, Pinus or Quercus (Stoffel and Perret 2006; Trappmann et al. 2013).

\section{Tangential Rows of Traumatic Resin Ducts}

Following cambium disturbance, TRDs are produced in the developing secondary xylem of certain conifer species such as Larix, Picea, Pseudotsuga or Abies (Bannan 1936; Yamaguchi and Lawrence 1993; Jacoby 1997; Stoffel 2008; Butler et al. 2010), where they extend both tangentially and axially from the injury (Bollschweiler et al. 2008a; Schneuwly et al. 2009a,b). When wounding occurs during the vegetation period of the tree, resin production will start within a few days after the impact and ducts will emerge within three weeks after the disturbance (Ruel et al. 1998; Luchi et al. 2005; Kaczka et al. 2010). Therefore, when analyzing cross-sections, the intra-seasonal position of the first series of TRDs can be used to reconstruct previous events with monthly precision (Stoffel et al. 2005b, 2008; Stoffel and Beniston 2006; Schneuwly-Bollschweiler and Stoffel 2012), provided that the incidents occurred during the vegetation period. With increasing axial and tangential distance from the impact, however, TRDs tend to migrate to later portions of the tree ring (Figure 1C; Bollschweiler et al. 2008a; Schneuwly et al. 2009a). The intraseasonal dating with monthly precision thus has to be based on cross-sections or a large number of increment cores at the same elevation on the stem. This technique cannot be used in Pinus because TRDs do not occur in this genus that produces copious amounts of resin and resin ducts unrelated to mechanical wounding (Phillips and Croteau 


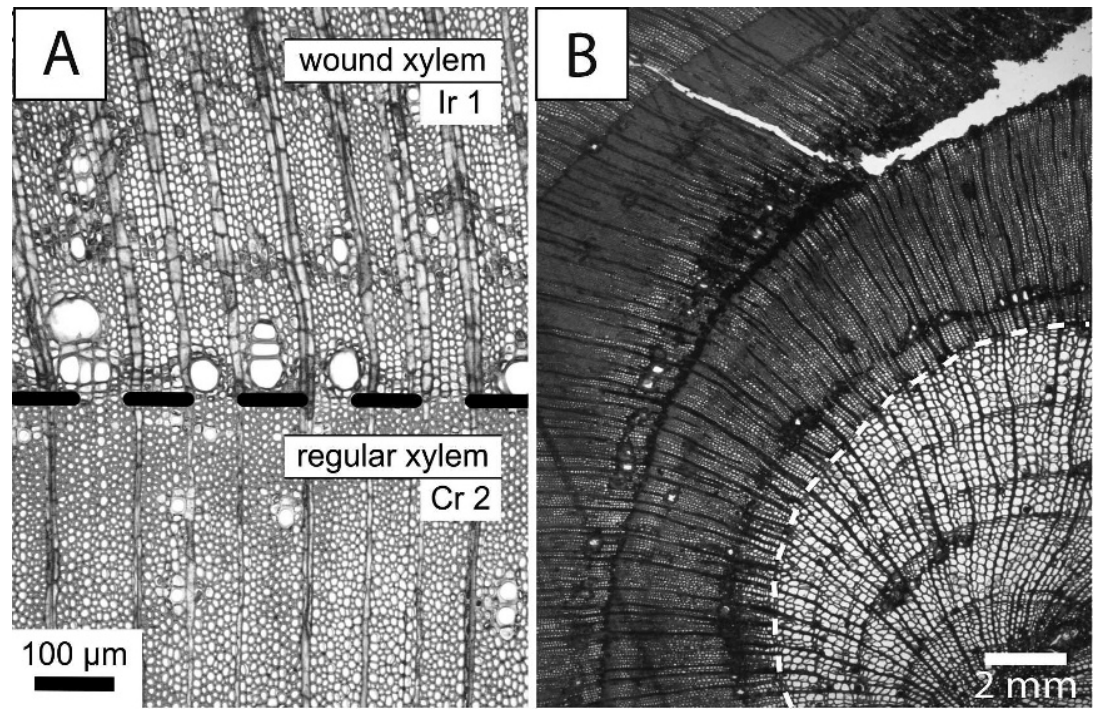

Figure 2. (A) Microscopic views of Fraxinus excelsior wood anatomy prior to and after cambial injury. The dashed line shows the position of the cambium at the time of wounding. More and narrower earlywood vessels were formed in the injury ring (Ir 1) as compared to the control ring $(\mathrm{Cr} 2)$. Wound xylem also differed from regular xylem through the enlargement of pre-existing rays. (B) Changes in tracheid lumina, tracheid number and ring width in a Pseudotsuga menziesii root following sudden exposure. The moment of exposure is indicated with the dashed line.

1999; Ballesteros et al. 2010a). Similar to wounds in young trees, trees with DBH $<5 \mathrm{~cm}$ should not be considered and the 10-15 innermost growth rings should be excluded, as tree rings in seedlings tend to produce more resin ducts per unit area in general (Larson 1994), but only a few ducts around wounds located near the pith (Bannan 1936).

\section{Tracheid and Vessel Anomalies}

Anomalies in tracheids and vessels have only rarely been used in the past to extract signals of geomorphic activity. Most work has been realized on riparian trees affected by floods and/or debris flows (e.g. St. George et al. 2002; Ballesteros et al. 2010b; Arbellay et al. 2010a,b; Wertz et al. 2013). Other processes, such as snow avalanches, were not studied frequently in the past (Arbellay et al. 2013). Tree microscopic response to wounding was primarily studied between rings formed in the year of disturbance and subsequent years as well as in uninjured control rings (Figure 2A). The authors state that injured rings are characterized by much smaller (but more) vessels as compared with uninjured rings, and that fiber and parenchyma cells (FPCs) would not differ significantly in numbers and size between injured and uninjured rings. Arbellay et al. (2010a) also stated that vessel and FPC parameters mainly remained constant with increasing tangential distance from the injury, except for a higher proportion of vessel lumen area opposite to the injury within $A$. incana. These results highlight the existence of anatomical tree-ring signatures - in the form of smaller vessels - related to past geomorphic process activity and address an innovative methodological approach to date injuries inflicted on broadleaved trees with minimally destructive techniques. More recently, Arbellay et al. (2012a,b) have expanded their approach to analyze the thickness-to-span ratio of vessels, xylem relative conductivity and xylem vulnerability to cavitation, and state that the wound-induced anatomical changes in wood structure express the functional need of trees to improve xylem hydraulic safety and mechanical strength at the expense of water transport. They conclude that xylem hydraulic efficiency was restored in one year, whereas xylem mechanical reinforcement and resistance to cavitation and decay lasted over several years.

Research on tracheid changes in conifers was basically limited to root exposure, with the 

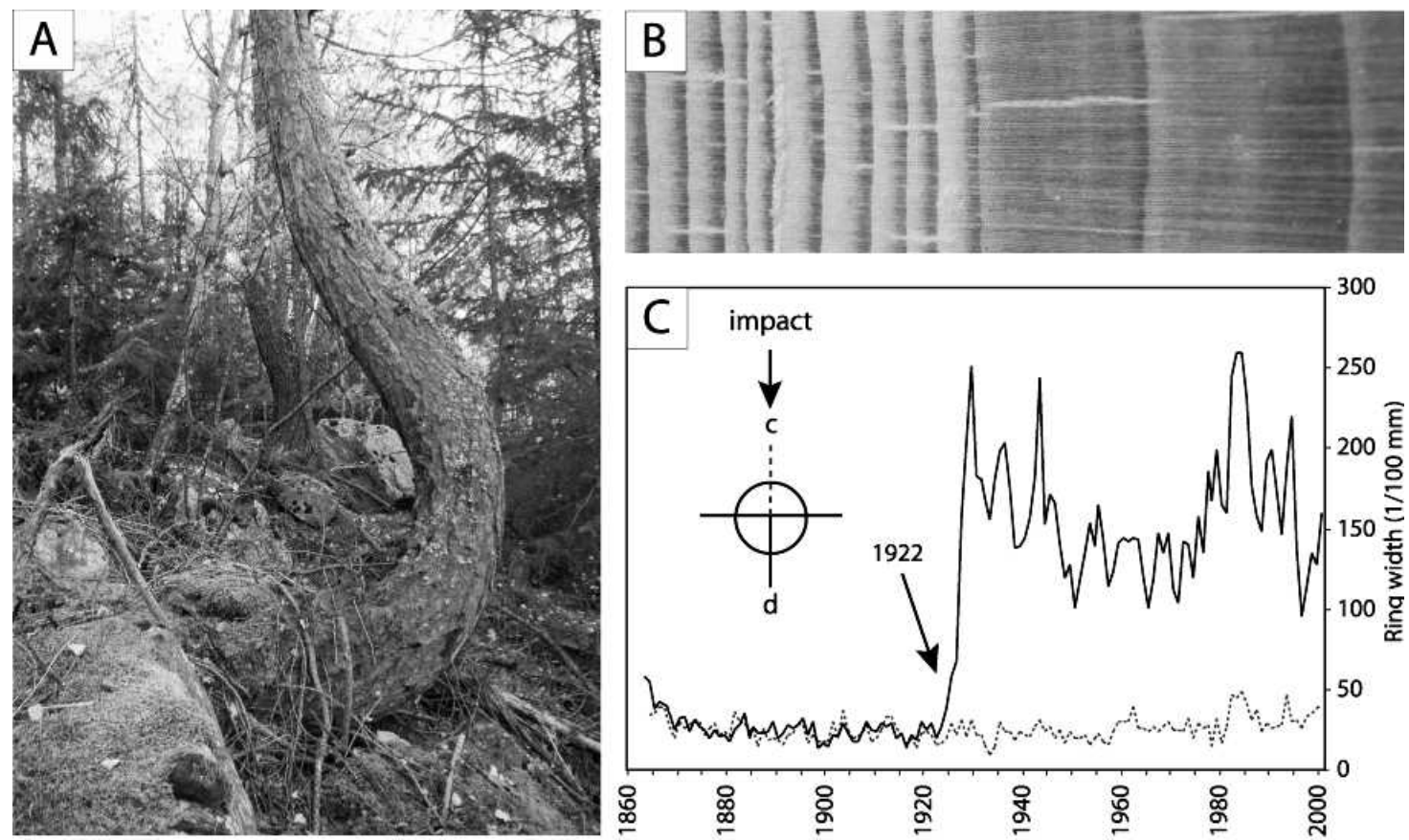

Figure 3. Evidence of tilting: (A) Tree morphology and (B) partial cross-sections of a tilted Larix decidua. (C) Increment curves of the upslope (dashed line) and downslope (solid line) radii from a Picea abies tree tilted by a debris flow in 1922.

exception of Stoffel and Hitz (2008) who identified changes in lumina of earlywood tracheids after wounding by snow avalanches and rockfalls. Exposed roots will continue to grow and fulfill their functions as long as their outer tips remain in the ground. In the exposed portion of the root, however, anatomical changes will occur (Stoffel et al. 2013b) and individual growth rings similar to those in the stem or branches will be formed. The localization of such changes in the tree-ring record allows determination of the moment of exposure (Figure 2b; Bodoque et al. 2006; Rubiales et al. 2008; Corona et al. 2010b, 2011; Lopez Saez et al. 2011; Stoffel et al. 2012). The continuous slow exposure of roots is usually caused by gradual processes and relatively low denudation rates, e.g. overland flow, slow opening of cracks in soils (e.g. soil creep, landslides) and in disintegrated bedrock, along rivers, streams, lakes and oceans (floods, shore erosion) as well as with faulting activity and displacements in relation to earthquake activity. Provided that the roots are gradually exposed with time, it is also possible to determine erosion rates in such cases (Carrara and Carroll 1979).

\section{Reaction Wood}

Inclination of the stem may result from the sudden pressure induced by hydrogeomorphic processes directly, by the associated deposition of material (e.g. avalanche snow, debris-flow material), or by the slow but ongoing destabilization of a tree through landslide activity or erosion (Lundström et al. 2007a,b). Tilted trees are common in most areas affected by geomorphic processes (Figure 3A) and have therefore been used in many publications focusing on the dating of event histories (e.g. Clague and Souther 1982; Braam et al. 1987a,b; Fantucci and Sorriso-Valvo 1999).

Subsequent growth in the trunk of a tilted tree will attempt to restore its vertical position and the reaction will be most clearly visible in that segment of the tree to which the center of gravity has been moved through the inclination of the stem axis (Mattheck 1993). In the tree-ring record, 
eccentric growth will be visible after a tilting event and thus will allow accurate dating of the disturbance. In conifers, compression wood (also referred to as reaction wood) will be produced on the underside of the trunk. Individual rings will be considerably larger and slightly darker in appearance as compared to the upslope side (Figure 3B). The difference in color results from much thicker and rounded cell walls of earlywood and latewood tracheids (Timell 1986; Du and Yamamoto 2007). Compression wood also tends to have a higher proportion of latewood, higher lignin content and higher density (Timell 1986). Multiple tilting events in the same stem may be recognized by changes in the amount, color or orientation of reaction wood series in the tree-ring record. In contrast, stem tilting in broadleaved trees leads to the formation of tension wood (Westing 1965) on the upper side facing the tilting agent. Broadleaved trees react upon tilting with ultra-structural modifications (e.g. fewer vessels of smaller diameter, higher cellulose content and a gelatinous layer oriented nearly parallel to the fiber axis) that are only visible when studied on micro-sections (Pilate et al. 2004).

\section{Growth Reduction}

Debris flows, floods, landslides or "dirty" snow avalanches may bury trees by depositing material around their stem base. Growth suppression after burial with debris is caused, on the one hand, by a reduced activity of the roots, and on the other hand, by mechanical effects caused by the enormous weight of debris. The effect of pressure on the cambial activity of trees has already been described by Kny (1877) and Rubner (1910). The pressure on the cambium exerted by bark and phloem impedes the cell division and leads to a reduced number of cells with narrower lumen (Kny 1877). Thus, the supply of water and nutrients will be temporarily disrupted or at least limited (LaMarche 1966; Hupp et al. 1987; Friedman et al. 2005) and the yearly increment will be diminished (Kogelnig-Mayer et al. 2013). By the pressure on the stem, the width of the growth rings may be reduced to a quarter of the original width (Rubner 1910). Reductions in annual ring widths in tilted trees are thought to be related to the partial destruction of root mass in the case of unstable slopes (Mayer et al. 2010).

If stem burial exceeds a certain threshold, trees will die from a shortage of water and nutrient supply (Figure 4A). According to case-study results from the Italian Dolomites (Strunk 1991), Picea abies may tolerate a maximum burial depth of 1.6 to $1.9 \mathrm{~m}$ in environments dominated by finegrained debris flows composed of calcareous and dolomitic material (Strunk 1997). Although there are no data available for other species or lithologies, it is believed that survivable burial depths will be much smaller in regions where debris flows are composed of massive or larger materials.

Bouncing rocks and boulders, debris in flowing water, debris flows and lahars or the windblast of snow avalanches may cause decapitation of trees (Figure 4B) or the removal of branches. The loss of the crown or branches is more common in bigger trees, when stems have lost their flexibility. Apex loss has also been observed as a result of rockfall impacts close to the ground level. In such cases, the sinusoidal propagation of shockwaves in the stem results in the break-off of the crown. This phenomenon has been described as whiplash or "hula-hoop" effect (Dorren and Berger 2006; Lundström et al. 2009).

Trees react upon decapitation or branch loss with distinct radial growth suppression (Figure 4C) in the years following the impact. One or several lateral branches will form a "leader" that replaces the broken crown, resulting in the tree morphology called "candelabra" growth (Butler and Malanson 1985; Stoffel et al. 2005a). "Leaders" may also be formed from prostrated trunks knocked over by geomorphic events.

Erosional processes and the (partial) denudation of roots may generate different growth reactions, both in the stem and in the exposed roots. The type and intensity of the reaction(s) will depend on the nature of the erosive event, which may be instantaneous or progressive and gradual. If several roots are completely denuded during a sudden erosive event (e.g. debris flow, lahar, flood or landslide), they are no longer able to fulfill their primary functions and quickly die. The tree subsequently suffers from a shortage of water and nutrient supply, resulting in suppressed tree 


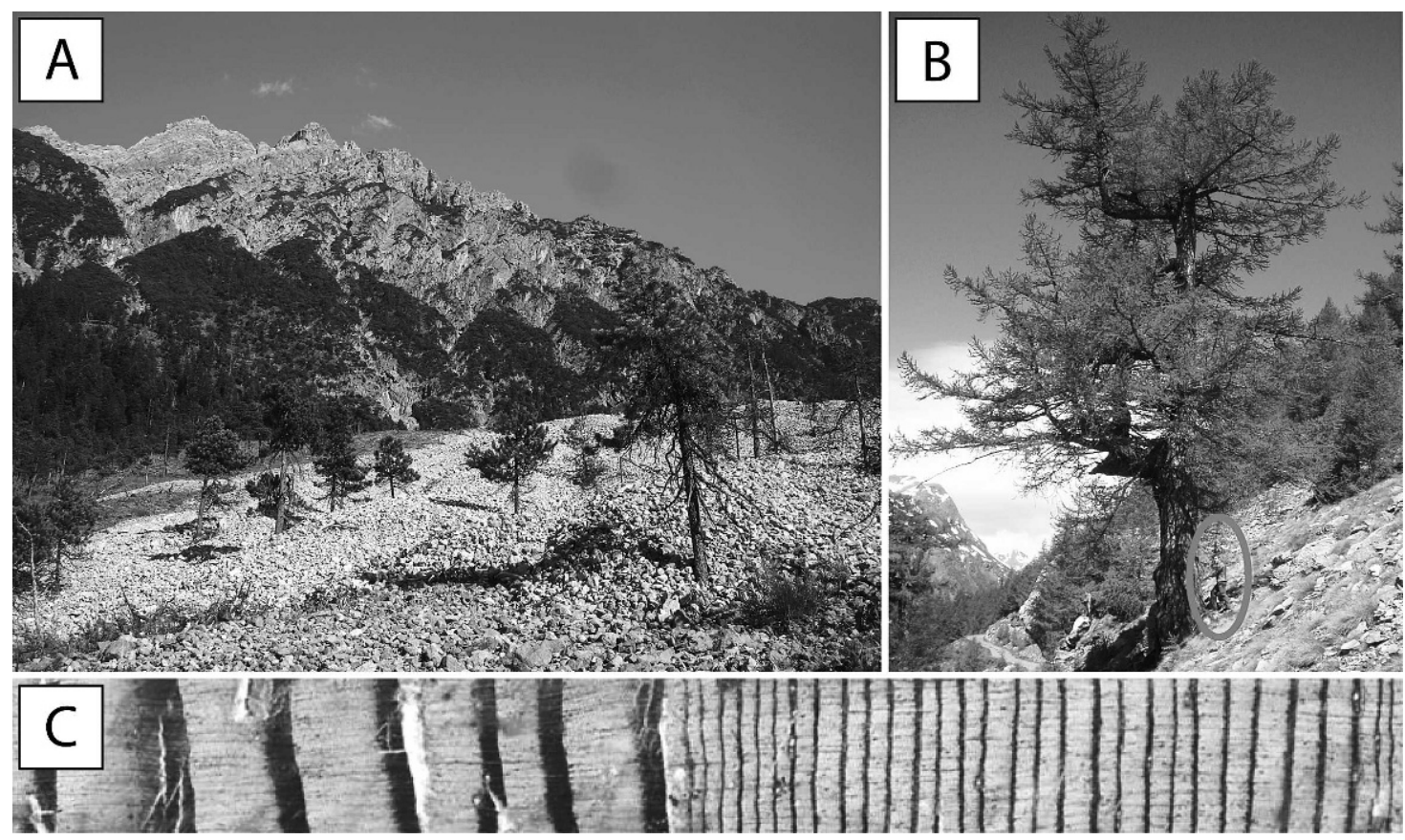

Figure 4. (A) The partial burial of trees, as illustrated here with Pinus mugo growing on a debris-flow cone, is one of the main reasons for the occurrence of abrupt growth suppression. (B) The loss of apices also causes growth suppression and can occur repeatedly in century-old Larix decidua trees affected by rockfall or snow avalanches. (C) Sudden growth suppression in Picea abies.

growth and the formation of narrow rings in the stem (LaMarche 1968; Carrara and Carroll 1979; McAuliffe et al. 2006).

\section{Growth Release}

Geomorphic processes do not only disturb trees in their growth, but large and devastating hydrogeomorphic events can also eliminate trees along channels or couloirs through uprooting and stem breakage while leaving their neighbors intact. This phenomenon can be observed with rockfalls (Stoffel et al. 2005a, 2011), debris flows (Stoffel et al. 2006; Bollschweiler and Stoffel 2010), lahars (Bollschweiler et al. 2009), extreme floods (RuizVillanueva et al. 2010; Ballesteros et al. 2011a,b), landslides (Lopez Saez et al. 2012a,b, 2013a,b) or snow avalanches (Butler 1979; Corona et al. 2010a, 2012, 2013b). The elimination of neighboring trees can result in a new environment with less competition, more light, nutrients and/or water. Survivor trees will benefit from the improved conditions and respond with a growth increase and wider tree rings (Strunk 1997). However, several observations indicate that this growth release in survivor trees can be delayed and that it may only become effective as soon as surviving vegetation can take full benefit of the excess availability of water, nutrients and light (Stoffel and Bollschweiler 2008). Therefore this GD cannot always be used to date past destructive events with precision. Because release phases may also be triggered through a combination of climatic and geomorphic effects (Strunk 1991), suddenly larger rings in survivor trees should not be used as the single indicator of past process activity, but as a means to corroborate the dating of geomorphic events identified in other trees of the same site and with other types of growth disturbances (Stoffel et al. 2010).

\section{Germination and Kill Dates}

Many geomorphic processes can eliminate surface vegetation including entire forest stands and therefore leave no direct dendrogeomorphic 
Table 2. Proposal for the definition of intensities of growth disturbances (GDs) based on their appearance and/or persistence in the tree-ring series. Note that tangential rows of traumatic resin ducts (TRDs) are formed in some conifer species (e.g. Abies, Larix, Picea, Pseudotsuga), but not in Pinus or in broadleaved species. Vessel anomalies are related to injuries and typical for broadleaved tree species.

\begin{tabular}{|c|c|c|c|c|}
\hline GD & Parameter & weak GD & moderate GD & strong GD \\
\hline Injuries, callus tissue & & N/A & N/A & clear indicator of an event \\
\hline TRDs & & $\begin{array}{l}\text { tangentially aligned } \\
\text { row with clear gaps } \\
\text { between ducts }\end{array}$ & $\begin{array}{l}\text { compact, but not fully } \\
\text { continuous row }\end{array}$ & $\begin{array}{l}\text { extremely compact and } \\
\text { continuous row }\end{array}$ \\
\hline \multirow[t]{2}{*}{ Vessel anomalies } & Decrease in lumen area $(\%)$ & N/A & N/A & $\geq 30 \%$ \\
\hline & Decrease in vessel number $(\%)$ & N/A & $\geq 30 \%$ & $\geq 50 \%$ \\
\hline Kill dates & & N/A & N/A & clear indicator of an event \\
\hline \multirow[t]{2}{*}{ Reaction wood } & $\begin{array}{l}\geq 50 \% \text { of ring width consists } \\
\text { of compression wood cells }\end{array}$ & & & \\
\hline & Duration & $\geq 3 \mathrm{yr}$ & $3-8 \mathrm{yr}$ & $\geq 8 \mathrm{yr}$ \\
\hline \multirow[t]{2}{*}{ Growth suppression } & change in ring width (\%) & $<60 \%$ & $\geq 100 \%$ & $\geq 200 \%$ \\
\hline & Duration & $\geq 4 \mathrm{yr}$ & $<8$ yr but $\geq 4 \mathrm{yr}$ & $\geq 8 \mathrm{yr}$ \\
\hline \multirow[t]{2}{*}{ Growth release } & change in ring width $(\%)$ & $<50 \%$ & $\geq 100 \%$ & $\geq 150 \%$ \\
\hline & Duration & $\geq 4 \mathrm{yr}$ & $<8 \mathrm{yr}$ but $\geq 4 \mathrm{yr}$ & $\geq 8 \mathrm{yr}$ \\
\hline
\end{tabular}

evidence. Surfaces cleared by devastating events will be recolonized with trees. Germination ages of trees growing on bare surfaces can be used to approximate the time of surface-clearing events (McCarthy and Luckman 1993; Pierson 2007; Bollschweiler et al. 2008b).

This approach provides a minimum age for that surface and has been used repeatedly to date landforms or to assess the minimum time elapsed since the last devastating event. Germination ages have been used in the past to date destructive snow avalanches, debris flows or floods (Sigafoos and Hendricks 1969; McCarthy and Luckman 1993; Heikkinen, 1994; Winter et al. 2002; Stoffel et al. 2006; Pierson 2007; Bollschweiler et al. 2008b). Yet, the assumption underpinning this approach is that new forest stands establish soon after the event. However, trees do not always immediately seed on new surfaces and there may be a period (so-called ecesis interval) between the time the new surface becomes available and the time that trees become established on it. Ecesis intervals have been discussed extensively in dendroglaciology (Koch 2009; McCarthy and Luckman 1993), indicating they range from one to almost 100 years, depending on the tree species, the nature of the substrate, and climate (Sigafoos and Hendricks 1969; Smith et al. 1995; Wiles et al. 1999; Lewis and Smith 2004). Somewhat shorter ecesis intervals have been reported for fluvial terraces cleared by lahars (10-15 years; Pierson 2007) and for a rockslide deposit with proximal seed sources (12 years; Van der Burght et al. 2012).

Trees killed by hydrogeomorphic events can be used for indirect dating of past process activity. Calendar kill dates (sensu Luckman 2000) were first used to crossdate stumps and logs with longlived, regional tree chronologies within the glacier forefield, which were overridden by a glacier. More recently, however, kill dates have also been used in avalanche research (e.g. Reardon et al. 2008).

\section{DEFINITION OF REACTION INTENSITY}

The expression of disturbance in the tree-ring record may vary in intensity as well as in the spatial and temporal extent between processes, species and age classes of trees. As a consequence, and based on the process and tree species analyzed, different classification systems have been used in the past. In the following, we present a synthesis of indicators commonly used in dendrogeomorphic research (Table 2) and make a proposal on how to analyze and interpret GDs in the future. Distinction is made between weak, moderate and strong GDs, following, inter alia, the classifications of Frazer (1985), Stoffel et al. (2005a) and Schneuwly et al. (2009b). 
Table 3. Proposal for the weighting of reactions in trees. Scars and strong TRDs are considered the most reliable indicators of past geomorphic disturbance. The presence of strong growth releases or weak reaction wood/TRDs in tree-ring records should be used only to confirm events, but not to date them in the first place.

\begin{tabular}{ll}
\hline Intensity & \multicolumn{1}{c}{ GDs in tree-ring record } \\
\hline Intensity 5 & impact scar, strong TRDs \\
Intensity 4 & kill date, moderate TRDs, callus tissue, strong decrease in vessel lumen area and/or vessel number, strong \\
& reaction wood, strong growth reduction \\
moderate reaction wood, moderate growth reduction, moderate decrease in vessel number \\
Intensity 3 & strong growth release, weak reaction wood \\
Intensity $\mathbf{2}$ & weak TRDs, moderate growth release \\
\hline
\end{tabular}

All GDs listed in Table 2 are typically induced by geomorphic disturbance, but several of them can be caused by other processes as well (e.g. anthropogenic or climatic disturbances, ungulate fraying or browsing). In addition to carefully analyzing the occurrence of geomorphic processes and other influences at the study site, one should therefore further minimize the risk of misdating events by maximizing signals and minimizing noise in the tree-ring record. As a rule of thumb, strong reactions in trees should be clearly preferred and weak reactions should be neglected. Based on the empirical rating systems proposed in the literature (Dubé et al. 2004; Reardon et al. 2008; Germain et al. 2009; Corona et al. 2010a, 2012, 2013b; Schläppy et al. 2013), which have been used mainly for the reconstruction of snow avalanches so far, we suggest the weighting of reactions as presented in Table 3.

Provided that a careful field reconnaissance precedes dendrogeomorphic sampling of trees, intensity 4 and 5 GDs can be considered the consequence of the geomorphic disturbance under investigation with high certainty. Depending on the nature of the process, intensity 3 reactions can be regarded as unequivocal signals of hydrogeomorphic disturbance as well (also see chapter 4 for details). Intensity $\mathbf{1}$ and $\mathbf{2}$ reactions, in contrast, should not be used as indicators of hydrogeomorphic disturbance in the first place, but can be included where appropriate, when it comes to the documentation of spatial patterns of past event occurrences (in terms of spread and reach), and only once the event years have been defined with intensity $\mathbf{4}$ and 5 reactions.

Identification of events is somewhat different in dendrogeomorphic rockfall research, where each strong and unequivocal GD will be considered an event. As a consequence, the selection of trees on rockfall slopes is even more crucial, so we suggest limiting the list of GDs considered for analysis to scars, TRDs, massive changes in anatomical signatures in broadleaved trees, strong growth reductions and compression wood of intensity classes 4 and 5. Figures 5 and 6 provide characteristic examples of intensity class 4 and 5 reactions.

Reactions of the same nature occurring in the same tree over several years should not be identified as individual events, but considered as a continuing response of the tree to initial disturbance. As a rule of thumb, one should consider that reactions were induced by different disturbance events as soon as a minimum of four "normal" rings exist between two rings with anomalous features. In conifers suffering from insect infestations, reactions to geomorphic disturbance - in particular compression wood - can be overprinted temporarily, and reactions to an initial geomorphic disturbance have been reported to occur again a few years after the insect infestation.

\section{DIFFERENT PROCESSES - DIFFERENT TYPES AND INTENSITIES OF REACTIONS}

The expression of disturbance in a tree (ring) will depend on the nature and intensity of the impact as well as on the sensitivity and vitality of the tree. The ability of a tree to react to disturbance is believed to be driven by the species-specific (genetic) make-up as well as by its age (Silhan et al. in press). Along this line of thought, observations of the authors suggest that (i) older trees tend to be less sensitive recorders of disturbance and that (ii) species with thick bark structures would require 

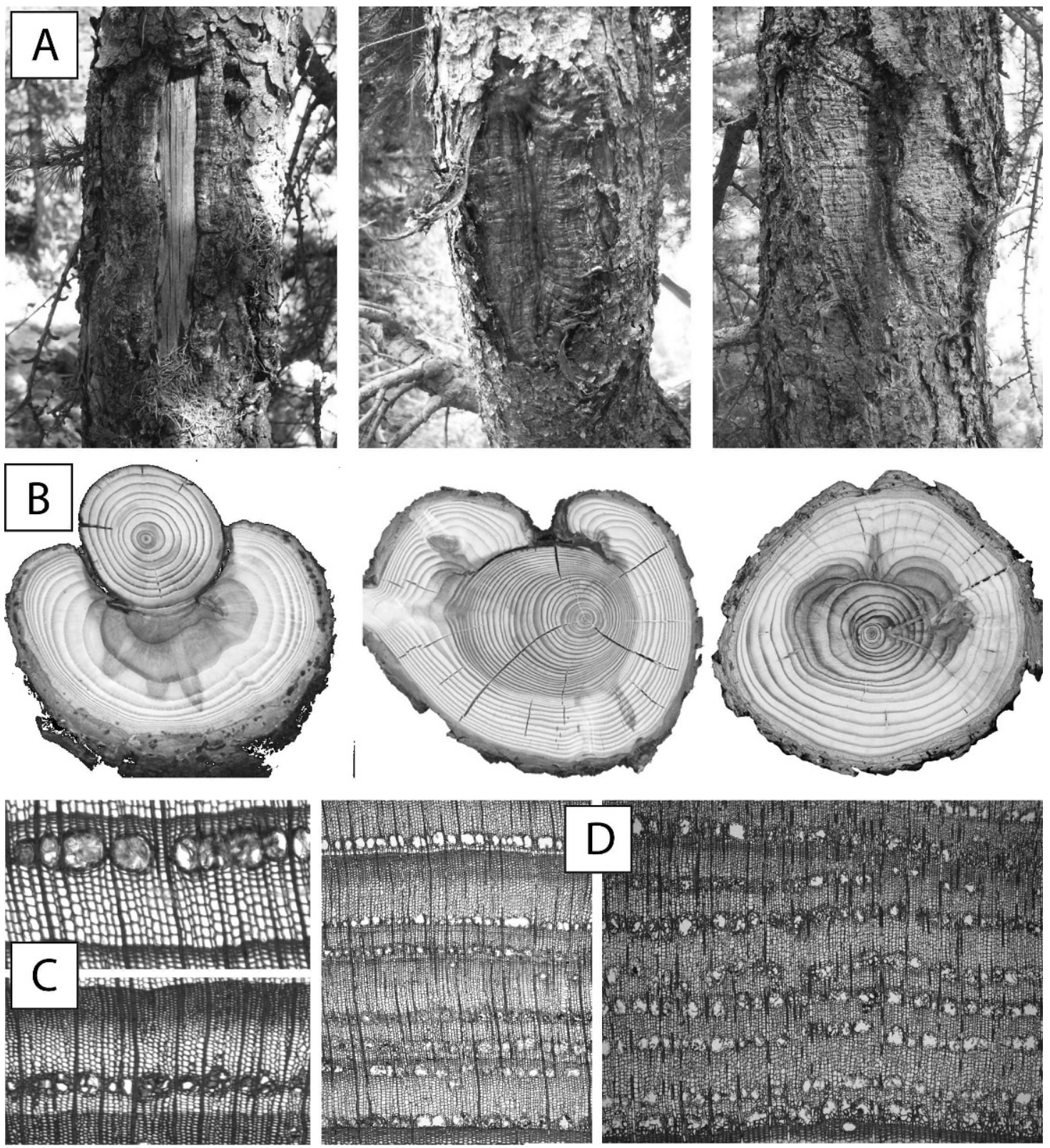

Figure 5. Overview of typical intensity 5 reactions: (A) Characteristic examples of and different stages of wound closure in Larix decidua injured by rockfall with (B) associated cross-sections. (C) Examples of strong tangential rows of traumatic resin ducts (TRDs) in Picea abies (top) and Larix decidua (bottom). (D) The production of TRD may persist over several years, depending on the production of hormonal signals. However, only the initial reaction should be considered the result of a geomorphic disturbance.

more intense impacts to record signs of geomorphic disturbance (Stoffel and Perret 2006; Trappmann and Stoffel 2013). The strength and/or onset of reaction wood, for instance (measured by the change in color, ring thickness, eccentricity, and/ or degree of circumference coverage of the crescent), has been demonstrated to vary from event to event within a single tree (Butler and Sawyer 2008), thereby pointing to changing sensitivity of recording trees with age. 

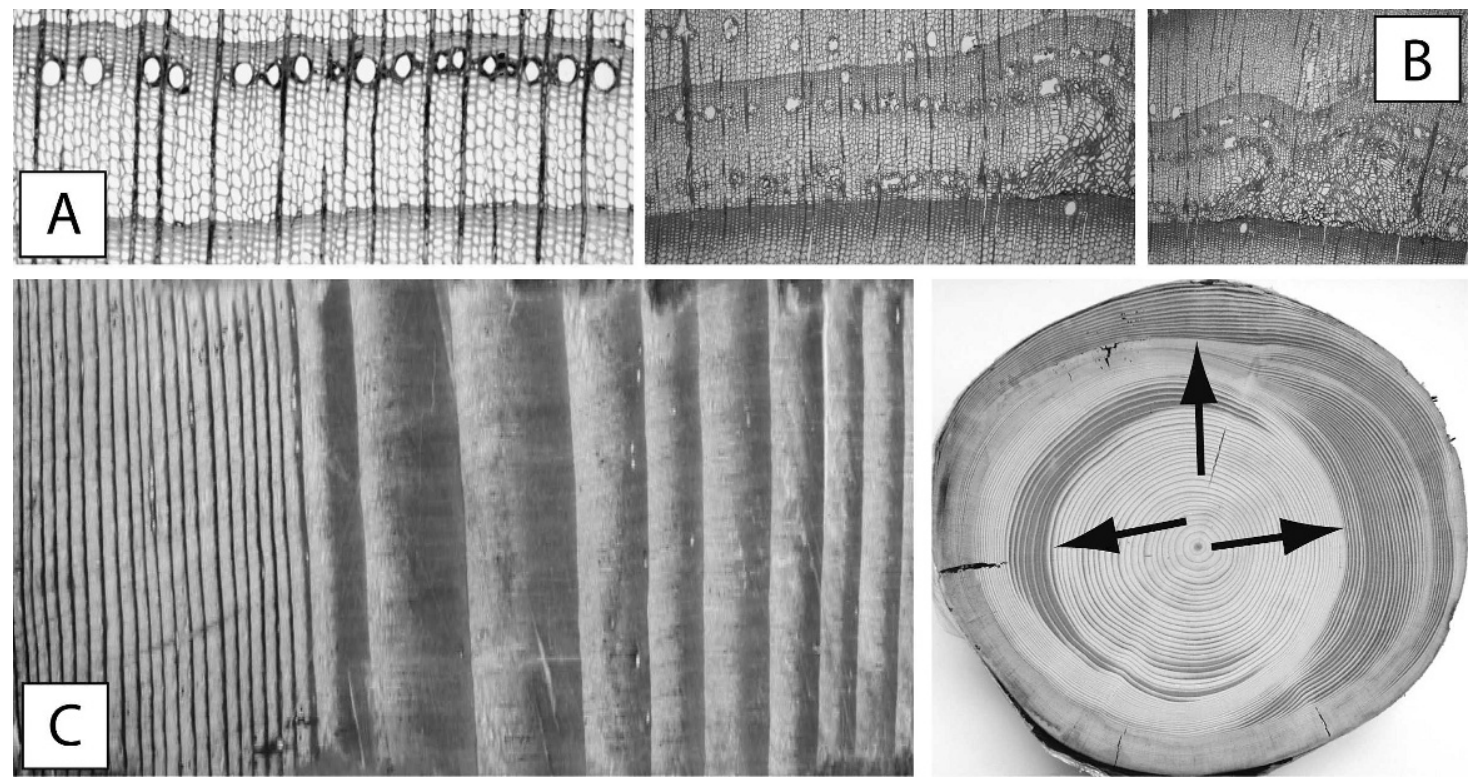

Figure 6. Overview of characteristic intensity 4 reactions: (A) Moderate TRD in Abies alba (left) and Larix decidua (right). Ducts are still aligned, but gaps exist between individual ducts. (B) Callus tissue occurring next to an injury in Larix decidua wounded by a snow avalanche. (C) Strong reaction wood in Larix decidua (left) and on a cross-section of Picea abies (right). At least three distinct events (arrow points to the initiation of each phase) can be identified in this tree sampled on a landslide body.

Moreover, the expression and intensity of disturbance as observed in the tree-ring record will also depend chiefly on the position of sampling, and reactions may be well developed in the vicinity of the impact but completely absent elsewhere in the stem. A spatially limited expression of disturbance is most obvious in the case of impact scars, associated TRDs (Bollschweiler et al. 2008a; Schneuwly et al. 2009a,b) and reaction wood (Timell 1986; Schneuwly et al. 2009b), whereas growth releases, abrupt growth suppression or vessel anomalies will be more widespread and visible throughout the stem (Arbellay et al. 2010a; Kogelnig-Mayer et al. 2013).

Remarkable differences also exist in the number, expression and intensity of GDs induced by different processes. In this way, processes with a large spatial footprint (e.g. snow avalanches, landslides) will tend to leave growth anomalies in a large number of trees. On an avalanche site, for instance, one may expect a distinct source area, a main track and a depositional surface, with GDs in trees being found (inside and) on both sides of the main track as well as in the depositional area. By contrast, rockfall will be characterized by a small-sized slope movement that typically involves a few boulders $\left(<5 \mathrm{~m}^{3}\right)$ and which will only cause damage to one or a few trees along its trajectory (Stoffel and Perret 2006; Moya et al. 2010; Corona et al. 2013a; Trappmann et al. 2013). In the same line of thought, Kogelnig-Mayer et al. (2011) demonstrated that the number of GDs induced by snow avalanches tends to be higher than that of debris flows because spread of debris flows tends to be more limited, thus resulting in a smaller number of potentially affected trees (SchneuwlyBollschweiler et al. in review).

Different geomorphic processes have also been demonstrated to determine the nature of GDs. Earthflows and rotational slides, for instance, usually result in the disruption and remodeling of topographic surfaces. As a consequence, survivor trees on landslides will preferably display tilting and root-plate damage (Moya et al. 2010), which will initiate the formation of reaction wood (Astrade et al. 1998) and abrupt growth reductions. Data from seven rotational landslides of the French Alps (Lopez Saez et al. 2013a) illustrate quite clearly the predominance of growth reductions (64\% of all GDs) and compression wood (33\%). Injuries were, by contrast, virtually absent (3\%) in their study 
Table 4. The nature and abundance of specific types of growth disturbances (GDs) in trees will be dictated by the nature of the geomorphic process, tree species considered for analysis and lithology (geologic units, mean and maximum grain sizes). LD = Larix decidua Mill.; PA = Picea abies (L.) Karst. Sources: A = Stoffel et al. (2005a); B = Trappmann and Stoffel (2013); C = Bollschweiler et al. (2007); D = Kogelnig-Mayer et al. (2011); E = Mayer et al. (2010); F = Stoffel et al. (2006); G = Savi et al. (2013).

\begin{tabular}{lcccccccc}
\hline Site/GD characteristics & Rockfall & Rockfall & Debris flow & Debris flow & Debris flood & Avalanche & Avalanche & Landslide \\
\hline Study site & Täschgufer & Hechenberg & Bruchi & Reiselehne & Gratzental & Reiselehne & Birchbach & Schimbrig \\
Sample size (nb) & 564 & 144 & 802 & 772 & 500 & 772 & 520 & 416 \\
Species & LD & PA & LD, PA & PA & LD, PA & PA & LD & PA \\
Lithology & Gneiss & Limestone & Granite & Granite & Limestone & Granite & Granite & Flysch \\
Scars/callus tissue & $2 \%$ & $11 \%$ & $4 \%$ & $6 \%$ & $1 \%$ & $4 \%$ & $7 \%$ & $1 \%$ \\
TRDs & $\mathbf{8 6 \%}$ & $\mathbf{8 9 \%}$ & $\mathbf{5 9 \%}$ & $\mathbf{8 0 \%}$ & $\mathbf{3 5 \%}$ & $\mathbf{5 7 \%}$ & $\mathbf{6 1 \%}$ & $21 \%$ \\
Reaction wood & $3 \%$ & $<1 \%$ & $15 \%$ & $3 \%$ & $6 \%$ & $\mathbf{1 7 \%}$ & $\mathbf{2 2 \%}$ & $\mathbf{2 5 \%}$ \\
Growth suppression & $6 \%$ & $0 \%$ & $12 \%$ & $9 \%$ & $\mathbf{2 8 \%}$ & $\mathbf{1 7 \%}$ & $6 \%$ & $\mathbf{4 7 \%}$ \\
Growth release & $3 \%$ & $0 \%$ & $10 \%$ & $2 \%$ & $\mathbf{3 0 \%}$ & $5 \%$ & $4 \%$ & $6 \%$ \\
Author & $A$ & $B$ & $C$ & $D$ & $E$ & $D$ & $F$ & $G$ \\
\hline
\end{tabular}

focusing on Pinus nigra. Based on the analysis of snow avalanches and debris flows known from archival records, Kogelnig-Mayer et al. (2011) demonstrated that trees from the same study site will react differently to different processes. In their case, debris flows were primarily causing injuries and TRDs (Table 4), whereas trees impacted by avalanche snow formed a much higher percentage of compression wood, growth reductions, and growth releases. When studying different processes, one thus needs to adapt the list of criteria used for process reconstructions.

Similarly, signal strength will not only depend on the nature of the process (debris floods with limited solid charge versus debris flows with limited water but much more solids, for example), but also on the nature of the material involved. In the Austrian Alps, Mayer et al. (2010) and Procter et al. (2011) have shown quite clearly that the deposition of calcareous debris may have fertilizing effects on Picea abies and Pinus uncinata, and therefore dampen or eliminate signs of growth reduction after stem burial. Provided that other types of disturbances are largely missing, weaker reactions (intensities 1 or 2) might need to be taken into account as well to allow reconstruction of all events.

\section{RECONSTRUCTION OF EVENTS - REDUCTION OF NOISE}

A single reaction does not make a geomorphic event - with the exception of rockfalls - and criteria therefore need to be defined for the definition of events and for the exclusion of noise. First of all, process reconstruction should focus clearly on the most obvious and strongest reactions (i.e. intensity classes 4 and 5; intensity 3 reactions should be considered as described in sections 3 and 4). The required minimal number of GDs for an event to be accepted will depend on the spatial footprint that the process under investigation can leave in the field, and may thus need to be adjusted on a case-by-case basis. Thresholds for the selection of events can be based on expert approaches (sensu Stoffel and Bollschweiler 2008) or indices (sensu Shroder 1978).

In the expert approach, event histories are obtained via a semi-quantitative analysis of trees disturbed by past geomorphic process activity (e.g. Stoffel et al. 2005c, 2006; Bollschweiler et al. 2007, 2008b). Definition of events is based on a careful site selection and on the position of reacting trees in their geomorphic context. Past process activity is not defined with a fixed threshold of reacting trees, but based on the spatial distribution of trees simultaneously showing GDs following geomorphic activity. At least three to five strong GDs (intensities $\mathbf{4}$ or $\mathbf{5}$ ) need to occur in the same sector of the study site or along the same flow path for an event to be accepted. The threshold is rather low, but facilitates the dating of smaller or erosive events (with incision rather than avulsion) to be detected in the tree-ring record. The semi-quantitative 
approach therefore allows detection of small and larger geomorphic events.

Reconstructions based on index values (It) go back to the work of Shroder (1978), who defined a fixed threshold based on the ratio between reacting and sampled trees (Butler and Sawyer 2008). Butler et al. (1987) suggested that the use of the "tree-ring response index" be dictated by the nature and geographic extent of the hazard under study, and argued that more samples and the use of a higher minimum response index would allow greater confidence in the event chronology constructed from tree rings. The authors also suggested that chronologies for geographically discrete processes (e.g. snow avalanches) should aim for a high sample density, whereas studies focusing on processes such as slow landslides or the movement of permafrost bodies would require less dense, but larger sample size. In avalanche research, index values ranged from $10 \%$ (e.g. Larocque et al. 2001; Reardon et al. 2008) to 40\% (Butler and Malanson 1985; Muntan et al. 2009), with the latter being suitable for the identification of extreme events. In debris-flow research, Kogelnig-Mayer et al. (2011) and Procter et al. (2012) proposed the use of a weighted index $\left(W_{i t}\right)$ for which the number of GDs, their intensity, number of trees available as well as the intraseasonal timing of GDs are taken into account.

Recent work by Corona et al. (2012) has demonstrated quite clearly that rigid index values may hamper an extensive and well-balanced reconstruction of past snow avalanche activity, and illustrated that the use of flexible index values (where It and GD are adjusted based on the number of samples available for analysis) would provide much more reliable results over the entire period covered by the reconstruction.

Interestingly, based on a classification and regression tree (CART) analysis, Schläppy et al. (2013) has recently demonstrated that the criteria used in the expert's approach to reject or accept snow avalanche events are comparable to those used in studies based on indices, and that results of both approaches are virtually identical in the end. On a site affected by debris flows, Schneuwly-Bollschweiler et al. (2013) reconstructed event histories with the expert's approach and with indices, and obtained virtually the same results as well (i.e. in terms of event frequency and event years).

\section{OUTLOOK AND CONCLUSIONS}

In this contribution, we illustrate the broad array of dendroecological indicators that are currently being used to reconstruct and interpret geomorphic disturbance events in trees. A large body of dendrogeomorphic papers has been published over the past few years (i.e. at least 75 papers for the period 2008-2012), and the focus of indicators used to infer past geomorphic events has clearly shifted towards scars and TRDs (Table 1). Although most studies are still performed with conifers, broadleaved species are slowly becoming more popular in dendrogeomorphology. A need for more fundamental research on broadleaved trees clearly exists, both in terms of wood anatomy of tension wood or scars and related changes in wood anatomy. An inclusion of new parameters will be likely more difficult for conifers, but new attempts should be undertaken to include wood density or isotope data contained in the tree-ring records for dendrogeomorphic purposes. Based on Table 4, one might also consider restricting dendrogeomorphic analyses to specific types of GDs, because different processes would preferentially cause certain types of reactions in the tree-ring record.

Recent advances in dendrogeomorphology have also demonstrated that the selection of trees and an adequate mixture of species and age classes are fundamental for the reconstruction of wellbalanced and minimally biased time series of past geomorphic activity (Trappmann and Stoffel 2013). Finally, the definition of events will need to be based on adequate absolute (GDs) and relative (It) numbers of trees with simultaneous growth disturbances to reconstruct geomorphic events from the tree-ring series (Stoffel et al. 2013a). Together with the optimization of minimum sample sizes, a more systematic definition, identification and weighting of GDs in dendrogeomorphology will ultimately lead to more robust, comparable and more reliable time series in the future, and thereby help to promote dendrogeomorphic techniques even further. 


\section{ACKNOWLEDGMENTS}

The authors are indebted to Associate Editor Håkan Grudd, John (Jack) Shroder and three anonymous reviewers for insightful comments and constructive feedbacks on an earlier version of the manuscript.

\section{REFERENCES CITED}

Alestalo, J., 1971. Dendrochronological interpretation of geomorphic processes. Fennia 105:1-139.

Arbellay, E., M. Stoffel, and M. Bollschweiler, 2010a. Wood anatomical analysis of Alnus incana and Betula pendula injured by a debris-flow event. Tree Physiology 30:1290-1298.

- 2010b. Dendrogeomorphic reconstruction of past debris-flow activity using injured broad-leaved trees. Earth Surface Processes and Landforms 35:399-406.

Arbellay, E., P. Fonti, and M. Stoffel, 2012a. Duration and extension of anatomical changes in wood structure after cambial injury. Journal of Experimental Botany 63: 3271-3277.

Arbellay, E., C. Corona, M. Stoffel, P. Fonti, and A. Decaulne, 2012b. Defining an adequate sample of earlywood vessels for retrospective injury detection in diffuse-porous species. PLoS ONE 7(6):e38824, doi:10.1371/journal.pone.0038824.

Arbellay, E., M. Stoffel, and A. Decaulne, 2013. Dating of snow avalanches by means of wound-induced vessel anomalies in subarctic Betula pubescens. Boreas 42:568-574.

Astrade, L., J. P. Bravard, and N. Landon, 1998. Mouvements de masse et dynamique d'un géosystème alpestre: étude dendrogéomorphologique de deux sites de la vallée de Boulc (Diois, France). Géographie physique et Quaternaire 52: 153-166.

Aulitzky, H., 1992. Die Sprache der "stummen Zeugen". In International Symposium Interpraevent "Schutz des Lebensraumes vor Hochwasser Muren und Lawinen", Bern, June 29-July 3, 1992, pp. 139-174. Klagenfurt, Forschungsgesellschaft für vorbeugende Hochwasserbekämpfung, Vol. 6.

Ballesteros, J. A., M. Stoffel, J. M. Bodoque, M. Bollschweiler, O. M. Hitz, and A. Diez, 2010a. Changes in wood anatomy in tree rings of Pinus pinaster Ait. following wounding by flash floods. Tree-Ring Research 66:93-103.

Ballesteros, J. A., M. Stoffel, M. Bollschweiler, J. M. Bodoque, and A. Díez, 2010b. Flash-flood impacts cause changes in wood anatomy of Alnus glutinosa, Fraxinus angustifolia and Quercus pyrenaica. Tree Physiology 30:773-781.

Ballesteros, J. A., J. M. Bodoque, A. Díez, M. Sanchez-Silva, and M. Stoffel, 2011a. Calibration of floodplain roughness and estimation of palaeoflood discharge based on tree-ring evidence and hydraulic modelling. Journal of Hydrology 403: $103-115$.

Ballesteros, J. A., M. Eguibar, J. M. Bodoque, A. Díez, M. Stoffel, and I. Gutiérrez, 2011b. Estimating flash flood discharge in an ungauged mountain catchment with 2D hydraulic models and dendrogeomorphic paleostage indicators. Hydrological Processes 25:970-979.
Bannan, M. W., 1936. Vertical resin ducts in the secondary wood of the Abietineae. New Phytologist 35:11-46.

Bodoque, J. M., A. Díez-Herrero, J. F. Martín-Duquea, J. M. Rubiales, A. Godfrey, J. Pedraza, R. M. Carrasco, and M. A. Sanz, 2006. Sheet erosion rates determined by using dendrogeomorphological analysis of exposed tree roots: two examples from Central Spain. Catena 64:81-102.

Bollschweiler, M., and M. Stoffel, 2010. Tree rings and debris flows: recent developments, future directions. Progress in Physical Geography 34:625-645.

Bollschweiler, M., M. Stoffel, M. Ehmisch, and M. Monbaron, 2007. Reconstructing spatio-temporal patterns of debris-flow activity with dendrogeomorphological methods. Geomorphology 87:337-351.

Bollschweiler, M., M. Stoffel, D. M. Schneuwly, and K. Bourqui, 2008a. Traumatic resin ducts in Larix decidua stems impacted by debris flows. Tree Physiology 28:255-263.

Bollschweiler, M., M. Stoffel, and D. M. Schneuwly, 2008b. Dynamics in debris-flow activity on a forested cone - A case study using different dendroecological approaches. Catena 72:67-78.

Bollschweiler, M., M. Stoffel, L. Vazquez Selem, and D. Palacios, 2009. Tree-ring reconstruction of past lahar activity at Popocatepetl volcano, Mexico. The Holocene 20:265-274.

Braam, R., E. Weiss, and P. Burrough, 1987a. Spatial and temporal analysis of mass movement using dendrochronology. Catena 14:573-584.

Braam, R. R., E. E. J. Weiss, and A. Burrough, $1987 \mathrm{~b}$. Dendrogeomorphological analysis of mass movement: A technical note on the research method. Catena 14:585-589.

Butler, D. R., 1979. Snow avalanche path terrain and vegetation, Glacier National Park, Montana. Arctic and Alpine Research 11:17-32.

Butler, D. R., and G. P. Malanson, 1985. A history of 643 highmagnitude snow avalanches, southern Glacier National Park, Montana, U.S.A. Mountain Research and Development 5: 175-182.

Butler, D. R., and C. F. Sawyer, 2008. Dendrogeomorphology and high-magnitude snow avalanches: a review and case study. Natural Hazards and Earth System Science 8: 303-309.

Butler, D. R., and M. Stoffel, 2013. Classics in physical geography revisited: John F. Shroder, Jr.'s 1978 and 1980 papers on dendrogeomorphology. Progress in Physical Geography 4: 161-188.

Butler, D. R., G. Malanson, and J. Oelfke, 1987. Tree-ring analysis and natural hazard chronologies: Minimum sample sizes and index values. The Professional Geographer 39: 41- 47 .

Butler, D. R., C. F. Sawyer, and J. A. Maas, 2010. Tree-ring dating of snow avalanches in Glacier National Park, Montana, U.S.A. In Tree Rings and Natural Hazards A State of the Art, edited by M. Stoffel, M. Bollschweiler, D. R. Butler, and B. H. Luckman, pp. 35-46. Springer, Heidelberg and New York.

Carrara, P. E., and T. R. Carroll, 1979. The determination of erosion rates from exposed tree roots in the Piceance Basin, Colorado. Earth Surface Processes 4:307-317. 
Clague, J. J., and J. G. Souther, 1982. The Dusty Creek landslide on Mount Caylay, British Columbia. Canadian Journal of Earth Sciences 19:524-539.

Corona, C., G. Rovéra, J. Lopez Saez, M. Stoffel, and P. Perfettini, 2010a. Spatio-temporal reconstruction of snow avalanche activity using tree rings: Pierres Jean Jeanne avalanche talus, Massif de l'Oisans, France. Catena 83: 107-118.

Corona, C., J. Lopez, G. Rovéra, L. Astrade, M. Stoffel, and F. Berger, 2010b. Quantification des vitesses d'érosion au moyen de racines déchaussées: validation de la méthode dans les badlands marneux des bassins versants expérimentaux de Draix (Alpes de Haute-Provence). Géomorphologie: Relief, Processus, Environnement 11:83-94.

Corona, C., J. Lopez, G. Rovéra, M. Stoffel, L. Astrade, and F. Berger, 2011. High resolution, quantitative reconstruction of erosion rates based on anatomical changes in exposed roots (Draix, Alpes de Haute-Provence) - critical review of existing approaches and independent quality control of results. Geomorphology 125:433-444.

Corona, C., J. Lopez Saez, M. Stoffel, M. Bonnefoy, D. Richard, L. Astrade, and F. Berger, 2012. How much of the real avalanche activity can be captured with tree rings? An evaluation of classic dendrogeomorphic approaches and comparison with historical archives. Cold Regions Science and Technology 74-75:31-42.

Corona, C., D. Trappmann, and M. Stoffel, 2013a. Parameterization of rockfall source areas and magnitudes with ecological recorders - when disturbances in trees serve the calibration and validation of simulation runs. Geomorphology, doi:10.1016/j.geomorph.2013.02.001.

Corona, C., J. Lopez Saez, M. Stoffel, G. Rovéra, J. L. Edouard, and F. Berger, 2013b. Seven centuries of avalanche activity at Echalp (Queyras massif, southern French Alps) as inferred from tree rings. The Holocene 23:292-304.

Dorren, L. K. A., and F. Berger, 2006. Stem breakage of trees and energy dissipation during rockfall impacts. Tree Physiology 26:63-71.

Douglass, A. E., 1941. Notes on the technique of tree-ring analysis. Tree-Ring Bulletin 7:28-34.

Du, S., and F. Yamamoto, 2007. An overview of the biology of reaction wood formation. Journal of Integrative Plant Biology 49:131-143.

Dubé, S., L. Filion, and B. Hétu, 2004. Tree-ring reconstruction of high-magnitude snow avalanches in the Northern Gaspé Peninsula, Québec, Canada. Arctic, Antarctic, and Alpine Research 36:555-564.

Fantucci, R., and M. Sorriso-Valvo, 1999. Dendrogeomorphological analysis of a slope near Lago, Calabria (Italy). Geomorphology 30:165-174.

Frazer, G. W., 1985. Dendrogeomorphic Evaluation of Snow Avalanche History at Two Sites in Banff National Park. Unpublished M.Sc. thesis, Department of Geography, University of Western Ontario, London, ON, Canada.

Friedman, J. M., K. R. Vincent, and P. B. Shafroth, 2005. Dating floodplain sediments using tree-ring response to burial. Earth Surface Processes and Landforms 30: 1077-1091.
Germain, D., L. Filion, and B. Hetu, 2009. Snow avalanche regime and climatic conditions in the Chic-Choc Range, eastern Canada. Climatic Change 92:141-167.

Heikkinen, O., 1994. Using dendrochronology for the dating of land surfaces. In Dating in Exposed and Surface Contexts, edited by C. Beck, pp. 213-235. University of New Mexico Press, Albuquerque.

Hupp, C. R., W. R. Osterkamp, and J. L. Thornton, 1987. Dendrogeomorphic Evidence and Dating of Recent Debris Flows on Mount Shasta, Northern California. US Geological Survey Professional Paper 1396-B, 39 pp.

Jacoby, G. C., 1997. Application of tree ring analysis to paleoseismology. Reviews of Geophysics 35:109-124.

Kaczka, R. J., A. Deslauriers, and H. Morin, 2010. Highprecision dating of debris-flow events within the growing season. In Tree Rings and Natural Hazards: A State-of-theArt, edited by M. Stoffel, M. Bollschweiler, D. R. Butler, and B. H. Luckman, pp. 227-229. Springer, Dordrecht, The Netherlands.

Kny, L., 1877. Das Dickenwachsthum des Holzkörpers an beblä Herten Sprossen und Wurzeln und seine Abhängigkeit von äusseren Einflüssen, insbesondere von Schwerkraft und Druck. Botanische Zeitschrift 35:415-423.

Koch, J., 2009. Improving age estimates for late Holocene glacial landforms using dendrochronology - Some examples from Garibaldi Provincial Park, British Columbia. Quaternary Geochronology 4:130-139.

Kogelnig-Mayer, B., M. Stoffel, M. Schneuwly-Bollschweiler, J. Hübl, and F. Rudolf-Miklau, 2011. Possibilities and limitations of dendrogeomorphic time-series reconstructions on sites influenced by debris flows and frequent snow avalanche activity. Arctic, Antarctic, and Alpine Research 43: 649-658.

Kogelnig-Mayer, B., M. Stoffel, and M. Schneuwly-Bollschweiler, 2013. Four-dimensional growth response of mature Larix decidua to stem burial under natural conditions. Trees — Structure and Function, doi:10.1007/s00468-013-0870-4.

LaMarche, V. C., 1966. An 800-year history of stream erosion as indicated by botanical evidence. US Geological Survey Professional Paper 550D, Washington, DC; pp. 83-86.

, 1968. Rates of Slope Degradation as Determined from Botanical Evidence, White Mountains, California. US Geological Survey Professional Paper 352-I, 45 pp.

Larocque, S. J., B. Hetu, and L. Filion, 2001. Geomorphic and dendroecological impacts of slushflows in central Gaspe Peninsula (Quebec, Canada). Geografiska Annaler, Series A: Physical Geography 83:191-201.

Larson, P. R., 1994. The Vascular Cambium: Development and Structure. Springer Verlag, Berlin.

Lewis, D. H., and D. J. Smith, 2004. Dendrochronological mass balance reconstruction, Strathcona Provincial Park, Vancouver Island, British Columbia, Canada. Arctic, Antarctic and Alpine Research 36:598-606.

Lopez Saez, J., C. Corona, M. Stoffel, G. Rovéra, L. Astrade, and F. Berger, 2011. Mapping of erosion rates in marly badlands based on a coupling of anatomical changes in exposed roots with slope maps derived from LiDAR data. Earth Surface Processes and Landforms 36:1162-1171. 
Lopez Saez, J., C. Corona, M. Stoffel, P. Schoeneich, and F. Berger, 2012a. Probability maps of landslide reactivation derived from tree-ring records: Pra Bellon landslide, southern French Alps. Geomorphology 138:189-202.

Lopez Saez, J., C. Corona, M. Stoffel, L. Astrade, F. Berger, and J.-P. Malet, 2012b. Dendrogeomorphic reconstruction of past landslide reactivation with seasonal precision: The Bois Noir landslide, southeast French Alps. Landslides 9: 189-203.

Lopez Saez, J., C. Corona, M. Stoffel, and F. Berger, 2013 b. High-resolution fingerprints of past landsliding and spatially explicit, probabilistic assessment of future reactivations: Aiguettes landslide, southeastern French Alps. Tectonophysics 602:355-369.

Lopez Saez, J., C. Corona, and M. Stoffel, 2013a. Climate change increases the frequency of snowmelt-induced landslides in the French Alps. Geology 41:619-622.

Luchi, N., R. Ma, P. Capretti, and P. Bonello, 2005. Systemic induction of traumatic resin ducts and resin flow in Austrian pine by wounding and inoculation with Sphaeropsis sapinea and Diplodia scrobiculata. Planta 221:75-84.

Luckman, B. H., 2000. The Little Ice Age in the Canadian Rockies. Geomorphology 32:357-384.

Lundström, T., M. Stoffel, and V. Stöckli, 2007a. Fresh-stem bending of fir and spruce. Tree Physiology 28:355-366.

Lundström, T. U. Heiz, M. Stoffel, and V. Stöckli, 2007b. Fresh-wood bending: linking the mechanical and growth properties of a Norway spruce stem. Tree Physiology 27: $1229-1241$.

Lundström, T., M. J. Jonsson, A. Volkwein, and M. Stoffel, 2009. Reactions and energy absorption of trees subject to rockfall: A detailed assessment using a new experimental method. Tree Physiology 29:345-359.

Mattheck, C., 1993. Design in der Natur. Rombach, Freiburg; $242 \mathrm{pp}$.

Mayer, B., M. Stoffel, M. Bollschweiler, J. Hübl, and F. Rudolf-Miklau, 2010. Frequency and spread of debris floods on fans: A dendrogeomorphic case study from a dolomite catchment in the Austrian Alps. Geomorphology 118:199-206.

McAuliffe, J. R., L. A. Scuderi, and L. D. McFadden, 2006. Tree-ring record of hillslope erosion and valley floor dynamics: Landscape responses to climate variation during the last $400 \mathrm{yr}$ in the Colorado Plateau, Northeastern Arizona. Global and Planetary Change 50:184-201.

McCarthy, D. P., and B. H. Luckman, 1993. Estimating ecesis for tree-ring dating of moraines - a comparative study from the Canadian Cordillera. Arctic and Alpine Research 25: 63-68.

Moya, J., J. Corominas, J. Pérez Arcas, and C. Baeza, 2010. Tree-ring based assessment of rockfall frequency on talus slopes at Solà d'Andorra, Eastern Pyrenees. Geomorphology 118:393-408.

Muntán, E., C. Garcia, P. Oller, G. Marti, A. Garcia, and E. Gutierrez, 2009. Reconstructing snow avalanches in the Southeastern Pyrenees. Natural Hazards and Earth System Science 9:1599-1612.

Osterkamp, W. R., C. R. Hupp, and M. Stoffel, 2012. The interactions between vegetation and erosion: new directions for research at the interface of ecology and geomorphology. Earth Surface Processes and Landforms 37:23-36.

Phillips, M. A., and R. B. Croteau, 1999. Resin-based defences in conifers. Trends in Plant Science 4:184-190.

Pierson, T. C., 2007. Dating young geomorphic surfaces using age of colonizing Douglas-fir in southwestern Washington and northwestern Oregon, U.S.A. Earth Surface Processes and Landforms 32:811-831.

Pilate, G., B. Chabbert, B. Cathala, A. Yoshinaga, J. C. Leple, F. Laurans, C. Lapierre, and K. Ruel, 2004. Lignification and tension wood. Comptes Rendus Biologies 327:889-901.

Procter, E., M. Bollschweiler, M. Stoffel, and M. Neumann, 2011. A regional reconstruction of debris-flow activity in the Northern Calcareous Alps, Austria. Geomorphology 132: 41-50.

Procter, E., M. Stoffel, M. Schneuwly-Bollschweiler, and M. Neumann, 2012. Exploring debris flow history and process dynamics using an integrative approach on a dolomitic cone in western Austria. Earth Surface Processes and Landforms 37:913-922.

Reardon, B. A., G. T. Pederson, C. J. Caruso, and D. B. Fagre, 2008. Spatial reconstructions and comparisons of historic snow avalanche frequency and extent using tree rings in Glacier National Park, Montana, U.S.A. Arctic, Antarctic, and Alpine Research 40:148-160.

Rubiales, J. M., J. M. Bodoque, J. A. Ballesteros, and A. Díez, 2008. Response of Pinus sylvestris roots to sheet-erosion exposure: an anatomical approach. Natural Hazards and Earth System Sciences 8:223-231.

Rubner, K., 1910. Das Hungern des Cambiums und das Aussetzen der Jahrringe. Naturwissenschaftliche Zeitschrift für Land- und Forstwirtschaft 8:212-262.

Ruel, J. J., M. P. Ayres, and P. L. Lorio, 1998. Loblolly pine responds to mechanical wounding with increased resin flow. Canadian Journal of Forest Research 28:596-602.

Ruiz-Villanueva, V., A. Díez-Herrero, M. Stoffel, M. Bollschweiler, J. M. Bodoque, and J. A. Ballesteros, 2010. Dendrogeomorphic analysis of flash floods in a small ungauged mountain catchment (Central Spain). Geomorphology 118:383-392.

Sachs, T., 1991. Pattern Formation in Plant Tissue. Cambridge University Press, Cambridge.

Savi, S., M. Schneuwly-Bollschweiler, B. Bommer-Denns, M. Stoffel, and F. Schlunegger, 2013. Geomorphic coupling between hillslopes and channels in the Swiss Alps. Earth Surface Processes and Landforms 38:959-969.

Schläppy, R., V. Jomelli, D. Grancher, M. Stoffel, C. Corona, D. Brunstein, N. Eckert, and M. Deschatres, 2013. A new tree-ring-based, semi-quantitative approach for the determination of snow avalanche events: Use of classification trees for validation. Arctic, Antarctic and Alpine Research 45: 383-395.

Schneuwly, D. M., M. Stoffel, and M. Bollschweiler, 2009a. Formation and spread of callus tissue and tangential rows of resin ducts in Larix decidua and Picea abies following rockfall impacts. Tree Physiology 29:281-289.

Schneuwly, D. M., M. Stoffel, L. K. A. Dorren, and F. Berger, 2009b. Three-dimensional analysis of the anatomical growth 
response of European conifers to mechanical disturbance. Tree Physiology 29:1247-1257.

Schneuwly-Bollschweiler, M., and M. Stoffel, 2012. Hydrometeorological triggers of periglacial debris flows in the Zermatt Valley (Switzerland) since 1864. Journal of Geophysical Research - Earth Surface 117:F02033, doi:10.1029/ 2011 JF002262.

Schneuwly-Bollschweiler, M., C. Corona, and M. Stoffel, 2013. How to improve dating quality and reduce noise in tree-ring based debris-flow reconstructions. Quaternary Geochronology 18:110-118.

Shigo, A. L., 1984. Compartmentalization - A conceptual framework for understanding how trees grow and defend themselves. Annual Review of Phytopathology 22:189-214.

Shroder, J., 1978. Dendrogeomorphological analysis of mass movement on Table Cliffs Plateau, Utah. Quaternary Research 9:168-185.

Sidle, R. C., and Y. Onda, 2004. Hydrogeomorphology: Overview of an emerging science. Hydrological Processes 18:597-602.

Sigafoos, R. H., and E. L. Hendricks, 1969. The time interval between stabilization of alpine glacial deposits and establishment of tree seedlings. US Geological Survey Professional Paper 650B:B89-B93.

Šilhán, K., T. Pánek, J. Hradecký, and M. Stoffel, in press. Regional, dendrogeomorphic chronologies of debris flows for the Crimean Mountains (Ukraine): Frequency, triggers and impacts of tree age on results. Earth Surface Processes and Landforms.

Smith, D. J., D. P. McCarthy, and M. E. Colenutt, 1995. Little Ice Age glacial activity in Peter Lougheed and Elk Lakes Provincial Parks, Canadian Rocky Mountains. Canadian Journal of Earth Sciences 32:579-589.

St. George, S., E. Nielsen, F. Conciatori, and J. Tardif, 2002. Trends in Quercus macrocarpa vessel areas and their implications for tree-ring paleoflood studies. Tree-Ring Research 58:3-10.

Stoffel, M., 2008. Dating past geomorphic processes with tangential rows of traumatic resin ducts. Dendrochronologia 26:53-60.

Stoffel, M., and M. Beniston, 2006. On the incidence of debris flows from the early Little Ice Age to a future greenhouse climate: A case study from the Swiss Alps. Geophysical Research Letters 33:L16404, doi:10.1029/2006GL026805.

Stoffel, M., and M. Bollschweiler, 2008. Tree-ring analysis in natural hazards research - an overview. Natural Hazards and Earth System Sciences 8:187-202.

Stoffel, M., and O. M. Hitz, 2008. Snow avalanche and rockfall impacts leave different anatomical signatures in tree rings of Larix decidua. Tree Physiology 28:1713-1720.

Stoffel, M., and C. Huggel, 2012. Effects of climate change on mass movements in mountain environments. Progress in Physical Geography 36:421-439.

Stoffel, M., and M. Klinkmüller, 2013. 3D analysis of anatomical reactions in conifers after mechanical wounding: First qualitative insights from X-ray computed tomography. Trees - Structure and Function 27:1805-1811.
Stoffel, M., and S. Perret, 2006. Reconstructing past rockfall activity with tree rings: Some methodological considerations. Dendrochronologia 24:1-15.

Stoffel, M., and D. J. Wilford, 2012. Hydrogeomorphic processes and vegetation: Disturbance, process histories, dependencies and interactions. Earth Surface Processes and Landforms 37:9-22.

Stoffel, M., D. Schneuwly, M. Bollschweiler, I. Lièvre, R. Delaloye, M. Myint, and M. Monbaron, 2005a. Analyzing rockfall activity (1600-2002) in a protection forest - A case study using dendrogeomorphology. Geomorphology 68:224-241.

Stoffel, M., I. Lievre, M. Monbaron, and S. Perret, 2005b. Seasonal timing of rockfall activity on a forested slope at Täschgufer (Swiss Alps) - A dendrochronological approach. Zeitschrift für Geomorphologie 49:89-106.

Stoffel, M., I. Lièvre, D. Conus, M. A. Grichting, H. Raetzo, H. W. Gärtner, and M. Monbaron, 2005c. 400 years of debris flow activity and triggering weather conditions: Ritigraben, Valais, Switzerland. Arctic, Antarctic and Alpine Research 37: 387-395.

Stoffel, M., M. Bollschweiler, and G.-R. Hassler, 2006. Differentiating past events on a cone influenced by debrisflow and snow avalanche activity - A dendrogeomorphological approach. Earth Surface Processes and Landforms 31: 1424-1437.

Stoffel, M., D. Conus, M. A. Grichting, I. Lièvre, and G. Maitre, 2008. Unraveling the patterns of late Holocene debris-flow activity on a cone in the Swiss Alps: Chronology, environment and implications for the future. Global and Planetary Change 60:222-234.

Stoffel, M., M. Bollschweiler, D. R. Butler, and B. Luckman, 2010. Tree Rings and Natural Hazards - A State-of-the-Art. Springer, Dordrecht; New York.

Stoffel, M., M. Bollschweiler, L. Vazquez-Selem, O. FrancoRamos, and D. Palacios, 2011. Dendrogeomorphic dating of rockfalls on low-latitude, high-elevation slopes: Rodadero, Iztaccíhuatl volcano, Mexico. Earth Surface Processes and Landforms 36:1209-1217.

Stoffel, M., A. Casteller, B. H. Luckman, and R. Villalba, 2012. Spatiotemporal analysis of channel wall erosion in ephemeral torrents using tree roots - An example from the Patagonian Andes. Geology 40:247-250.

Stoffel, M., D. R. Butler, and C. Corona, 2013a. Mass movements and tree rings: A guide to dendrogeomorphic field sampling and dating. Geomorphology 200:106-120.

Stoffel, M., C. Corona, J. A. Ballesteros Canovas, and J. M. Bodoque del Pozo, 2013b. Vegetation-based dating and quantification of erosion processes. Earth-Science Reviews 123:18-34

Stokes, M. A., and T. L. Smiley, 1968. An Introduction to TreeRing Dating. University of Chicago Press, Chicago.

Strunk, H., 1991. Frequency distribution of debris flow in the Alps. Zeitschrift für Geomorphologie N.F. Supplement 83: 71-81.

, 1997. Dating of geomorphological processes using methods. Catena 31:137-151.

Timell, T. E., 1986. Compression Wood in Gymnosperms. Springer, Berlin. 
Trappmann, D., and M. Stoffel, 2013. Counting scars on tree stems to assess rockfall hazards: A low effort approach, but how reliable? Geomorphology 180-181:180-186.

Trappmann, D., C. Corona, and M. Stoffel, 2013. Rolling stones and tree rings: A state of research on dendrogeomorphic reconstructions of rockfall. Progress in Physical Geography 37:701-716.

Van der Burght, L., M. Stoffel, and C. J. Bigler, 2012. Analysis and modelling of tree succession on a recent rockslide deposit. Plant Ecology 213:35-46.

Varnes, D. J., 1978. Slope movement types and processes. In Landslides, Analysis and Control, edited by R. L. Schuster, and R. J. Krizek, pp. 11-33. Transportation Research Board Special Report 176, National Academy of Sciences

Wertz, E. L., S. St. George, and J. D. Zeleznik, 2013. Vessel anomalies in Quercus macrocarpa tree rings associated with recent floods along the Red River of the North, United States. Water Resources Research 49, doi:10.1029/2012WR012900.
Westing, A. H., 1965. Formation and function of compression wood in gymnosperms II. Botanical Reviews 34:51-78.

Wiles, G. C., D. J. Barclay, and P. E. Calkin, 1999. Tree-ring dated 'Little Ice Age' histories of maritime glaciers from western Prince William Sound, Alaska. The Holocene 9: 163-173.

Winter, L. E., L. B. Brubaker, J. F. Franklin, E. A. Miller, and D. Q. DeWitt, 2002. Initiation of an old-growth Douglas-fir stand in the Pacific Northwest: A reconstruction from treering records. Canadian Journal of Forest Research 32: 1039-1056.

Yamaguchi, D. K., and D. B. Lawrence, 1993. Tree-ring evidence for 1842-1843 eruptive activity at the Goat Rocks dome, Mount St. Helens, Washington. Bulletin of Volcanology 55:264-272.

Received 15 April 2013; accepted 1 August 2013. 